\title{
1. The concept of armed conflict
}

International humanitarian law can be generally defined as the body of international law governing the conduct of armed conflicts. The notion of armed conflict is therefore central to understanding this area of law. This is true both in terms of the philosophical underpinnings of international humanitarian law and in terms of the legal rules that set out the limits of its operation. The guiding principles of international humanitarian law arise from the need to place limits on the conduct of armed conflicts. These restraints are needed due to what we will call the morally exceptional nature of warfare. The philosophical concept of warfare will therefore be our first focus in this chapter.

We will then turn to the legal limits on the operation of international humanitarian law. The fundamental principle here is that international humanitarian law has no operation unless an armed conflict exists. This raises the important question of what constitutes an 'armed conflict'. We will therefore examine the legal definition of armed conflict, before turning to related questions concerning the duration and scope of hostilities. Finally, we will consider the legal distinction between international and non-international armed conflicts. This distinction has historically played an important role in international law. However, as we will see, its importance is diminishing over time.

\section{THE LOGIC OF WARFARE}

It is worthwhile to begin by reflecting on the morally exceptional character of armed conflict. It is widely seen as permissible and perhaps even praiseworthy for people engaged in warfare to deliberately set out to injure and kill others. This is, to put it mildly, quite different from the moral framework that governs human interaction in everyday life. In the normal moral codes of almost every human community, setting out deliberately to injure and kill other people is one of the very worst things you can do. This common view of warfare therefore posits a radical exception to the normal moral paradigm.

Let us assume the morally exceptional status of armed conflict for 
present purposes and ask where that idea leads. We might call this the question of the logic of warfare. It is sometimes said that 'all is fair in war', meaning that all moral rules are suspended. This is the notion of absolute warfare. The concept of absolute warfare is often associated with the Prussian military theorist Carl von Clausewitz (1780-1861). Clausewitz famously argued that armed conflicts tend naturally to escalate towards a state of absolute warfare. ${ }^{1}$ The idea that the sole aim of warfare is to defeat your opponent and normal moral rules do not apply leads logically to the conclusion that any and all means are justified.

In warfare, then, it seems that all bets are off. The goal of all parties in the conflict must be to secure victory and bring about the return of normal moral relations. Any measures that promote this end are permissible. Clausewitz is often interpreted as having fully endorsed this conclusion, but in fact he was ambivalent about it. He thought that the logic of warfare, if followed to its natural conclusion, means that the end justifies the means. However, he also noted that in actual wars, which are for limited purposes, absolute warfare is unsustainable, as it allows no conclusion short of total annihilation. ${ }^{2}$ A state of absolute warfare will not truly end until one side is completely destroyed.

\section{HUMANITARIANISM}

The morally exceptional nature of warfare means that the most important goal is to bring about peace. Absolute warfare might end the conflict, but it is not the best way to secure a peaceful conclusion. Rather, it would end the war at the cost of totally destroying one of the parties. It seems, then, that we need an alternative to absolute warfare. Rather than seeking an end to war at all costs, we need to conduct armed conflicts in such a way as to leave open the possibility of a lasting peace. This is perhaps the fundamental idea behind the doctrine of humanitarianism. Humanitarianism brings moral limits back into war by seeking to moderate the effects of warfare in the name of human ideals.

Humanitarianism responds to the unusual situation that arises in armed conflicts by adopting an approach of moderation. Although war necessarily involves suffering, there are basic values that unite humans even in wartime. This means that even war has limits. Humans are not inclined to

\footnotetext{
1 Carl von Clausewitz, On War (JJ Graham tr, Wordsworth 1997) 6-7 [bk I, ch I, §3].

2 Ibid 22-3 [bk I, ch I, §25].
} 
live in a permanent state of warfare and the wounds left by war will eventually have to be tended. It is therefore necessary to maintain a commitment to human ideals on which community may be founded following the cessation of hostilities. In this way, international humanitarian law aims to ensure respect for the most basic human values, such as dignity, community and freedom from suffering. It represents the last-ditch hold-out position of the human community against absolute warfare.

\section{Classical Origins}

The historical development of the idea that humanitarianism moderates warfare laid the foundations for the contemporary body of rules that constitutes international humanitarian law. Despite the moral strangeness of armed conflicts, human communities have long accepted the importance of mitigating the effects of warfare. For example, there is evidence that warfare between Ancient Greek city states around 700 to 450 BCE was governed by customary rules, concerned among other things with the treatment of prisoners of war and the extent to which defeated forces should be pursued. ${ }^{3}$ The influence of these rules is apparent in Plato's Republic, written around $375 \mathrm{BCE}$, where it is noted that citizens of occupied territories should not be enslaved or attacked, corpses should not be robbed and conquering forces should refrain from burning houses or destroying occupied lands. ${ }^{4}$

Plato's central reason for approving these principles concerned the common values that united the Greek nations. He noted the importance of maintaining goodwill between states even in times of armed conflict, in order to facilitate the progress of their common culture. Although Plato was not prepared to extend this approach to wars between Greeks and other races, whom he considered 'barbarians', his emphasis on the need to maintain a sense of common value during armed hostilities, in order to pave the way for future reconciliation between the parties, foreshadowed modern humanitarianism. We will discuss the limits on the Ancient Greek idea of humanitarianism further below.

Another important antecedent to modern humanitarian theories is found in the writings of Plato's pupil, Aristotle (384-322 BCE). Aristotle's theories on law and politics have been highly influential in shaping

3 Josiah Ober, 'Classical Greek Times' in Michael Howard, George J Andreopoulos and Mark R Shulman (eds), The Laws of War: Constraints on Warfare in the Western World (Yale University Press 1994).

4 Plato, Republic (Desmond Lee tr, Penguin 1987) 197-9 [bk V, §§469-71]. 
modern Western legal systems. His conception of the political community has been particularly important. Aristotle viewed humans as naturally social animals, who possess a common understanding of a good and fulfilling life. According to this shared conception of the good life, called eudaimonia, the highest form of human existence is characterised by full participation in the political community. ${ }^{5}$ This emphasis on shared values and the importance of community in human existence finds modern expression in the rules of international humanitarian law.

Humanitarian attitudes towards warfare can be discerned in other classical traditions. Although the Roman armies developed a reputation for fierceness in pursuit of military objectives, ${ }^{6}$ Cicero argued in $D e$ Officiis in $44 \mathrm{BCE}$ that certain standards must be observed in the conduct of warfare. In particular, he contended that forces should refrain from inflicting unnecessary devastation upon occupied territories, and captured opponents not guilty of excessive brutality during combat should be protected. ${ }^{7}$ Cicero's position was motivated by the idea that there are important principles of justice common to all human communities. He emphasised that hostilities should always be conducted with the aim of securing a lasting and equitable peace. Unlike Plato, Cicero did not distinguish in this respect between his fellow Romans and members of other cultures.

\section{Early Modern Developments}

Customary rules regulating warfare persisted through to the Middle Ages, when the first attempts were made to formalise the rules. These initially took the form of official proclamations. The Ordinance for the Government of the Army, published in 1386 at the order of Richard II of England, prohibited acts of violence against women and priests, as well as the burning of houses and the desecration of churches. Proclamations to a similar effect were issued by Henry V of England in 1415 and $1419,{ }^{8}$ Ferdinand of Hungary in 1526, Emperor Maximilian II in 1570 and King

5 For an overview of Aristotle's legal and political theory, see Jonathan Crowe, Legal Theory (Thomson Reuters 2009) 18-22.

6 Robert C Stacy, 'The Age of Chivalry' in Michael Howard, George J Andreopoulos and Mark R Shulman (eds), The Laws of War: Constraints on Warfare in the Western World (Yale University Press 1994).

7 Cicero, De Officiis (Walter Miller tr, Harvard University Press 1913) 37 [bk I, $\S X I], 83$ [bk I, §XXIV].

8 Theodor Meron, 'Shakespeare's Henry the Fifth and the Law of War' (1992) 86 American Journal of International Law 1, 23-4. 
Gustavus II Adolphus of Sweden in 1621. ${ }^{9}$ These instruments show that common international standards governing warfare were in place long before any formal agreements on the topic were concluded.

One of the most important modern works on international humanitarian law, Hugo Grotius' On the Law of War and Peace (1625), also dates from this period. The first two books of that work are mainly concerned with how a war may justly be commenced - in other words, the jus ad bellum. The third and final book, however, discusses what behaviour is permissible once war has started - that is, the jus in bello or international humanitarian law. Grotius' examination of the law of war is notable for his purposive view of human nature, which echoes Aristotle's emphasis on humanity's shared sense of value. In particular, Grotius emphasises that armed conflicts should always be conducted with a view to creating a lasting peace, again laying the foundations for modern humanitarianism. ${ }^{10}$

Grotius' writings contain many of the fundamental principles of contemporary international humanitarian law that we will encounter throughout this book. For example, he argues that combatants should take steps to avoid causing injury to civilians caught up in fighting, that prisoners of war should be treated humanely and that armed forces should avoid causing unnecessary damage to the regions through which they pass during the conflict. However, it was to be more than 200 years before these principles began to find formal expression in international legal agreements.

The preceding paragraphs by no means provide a complete account of the development of humanitarian ideas. However, they illustrate that the formal documents at the heart of modern international humanitarian law reflect a long customary tradition. This point is central to understanding the standards governing contemporary armed conflicts. Considered apart from this customary background, modern treaties concerning humanitarian law might well seem vague, incomplete and unenforceable. It is only when these documents are understood as attempts to formalise a robust tradition of unwritten principles that one appreciates why their provisions are so widely respected and obeyed.

9 See generally Edoardo Greppi, 'The Evolution of International Criminal Responsibility under International Law' (1999) 835 International Review of the Red Cross 531; Kenneth Ögren, 'Humanitarian Law in the Articles of War Decreed in 1621 by King Gustavus II Adolphus of Sweden' (1996) 313 International Review of the Red Cross 438; MH Keen, The Laws of War in the Late Middle Ages (Routledge and Kegan Paul 1965).

10 Hugo Grotius, On the Law of War and Peace (Francis W Kelsey tr, Clarendon Press 1925) vol II, 860-62 [bk III, ch XXV]. 


\section{INSIDERS AND OUTSIDERS}

We have already seen that the classical doctrine of humanitarianism espoused by Ancient Greek authors like Plato and Aristotle was limited in scope. The Ancient Greeks did not extend humanitarian principles to 'barbarians', but only to other Greeks. Barbarians, like women and slaves, were not considered members of the polis (city state or political community), which for the Greeks was equivalent to the moral community. It was assumed that non-citizens did not share common aspirations and values with citizens, so there was no need to extend them humanitarian consideration.

This feature of the Ancient Greek worldview marks a fundamental difference from modern humanitarianism. The version of the doctrine that lies behind international humanitarian law posits a global moral community. On this view, all humans are entitled to respect by virtue of their shared nature and values. Another way of putting this is that modern humanitarianism is committed to cosmopolitanism: the view that the whole world is a single moral community. The term comes from a statement attributed to the radical Ancient Greek thinker Diogenes the Cynic (c 412-323 BCE), founder of the Stoic school of philosophy: 'I am a citizen of the world [kosmopolitês].'

Diogenes was a great philosopher whose ideas are still influential today. However, he was a very strange man. He is reputed to have lived in a large tub and dined mainly on onions. Other stories involve him masturbating, spitting and defecating in public to mock prudish customs. He is also reputed to have wandered around in daytime with a lamp, saying, 'I am only looking for a true human being'. This story reflects the extent to which he rejected the worldview of his fellow Athenian citizens. The division between insiders and outsiders, marked by the conferral of citizenship, was firmly ingrained in Ancient Greek culture. Diogenes, however, questioned the distinction.

It may seem obvious to us today that cosmopolitanism is correct. ( $O f$ course we should extend the same moral standards to everyone!) However, it arguably still goes against some widespread practices and beliefs. For example, we commonly think it is legitimate to extend greater consideration to family members and fellow nationals than to those more distant from us. Is this type of partiality legitimate? There is a lively philosophical debate on these issues. ${ }^{11}$ There is no scope to pursue the topic fully here,

11 See, for example, Harry Brighouse and Adam Swift, 'Legitimate Parental Partiality' (2009) 37 Philosophy and Public Affairs 43; Harry Brighouse, 'Justifying 
but it illustrates the potentially radical implications of cosmopolitanism as a doctrine. We should not be too quick to simply declare that 'we are all cosmopolitans now!' International humanitarian law, however, has clear affinities with the cosmopolitan outlook.

\section{JUS AD BELLUM AND JUS IN BELLO}

We defined international humanitarian law at the start of this chapter as the body of international law governing the conduct of armed conflicts. The existence of an armed conflict is therefore a necessary prerequisite for international humanitarian law to operate. It is important to note in this context that international humanitarian law is concerned with regulating the conduct of armed conflicts, rather than their commencement. It is not concerned with how a conflict started or who was to blame for it, but rather stipulates what forms of conduct are permissible once the war is ongoing.

The body of international law relating to the conduct of armed conflicts is sometimes referred to using the Latin term jus in bello ('law in war'). This is generally viewed as synonymous with what we now call international humanitarian law. The law relating to the commencement of armed conflicts, by contrast, is known as the jus ad bellum ('law to war'). It is also sometimes called the jus contra bellum ('law against war'), since its primary concern is to stem the proliferation of armed disputes.

The distinction between the jus in bello and the jus ad bellum is fundamental to international humanitarian law. The objective of this field of law is to set up a body of rules that applies consistently to all parties to an armed conflict. It thereby avoids the need to draw difficult and controversial distinctions between just and unjust conflicts. It also avoids passing judgment on which of the parties to a conflict may be at fault. It simply applies the same fundamental guarantees and responsibilities to everyone.

\section{THE PRINCIPLE OF NEUTRALITY}

We might call this feature of international humanitarian law the principle of neutrality. There is a good reason why international humanitarian law

Patriotism' (2006) 32 Social Theory and Practice 547; Igor Primoratz, 'Patriotism: A Deflationary View' (2002) 33 Philosophical Forum 443; Peter Singer, Practical Ethics (2nd edn, CUP 1993) 232-4; Mark C Murphy, Natural Law in Jurisprudence and Politics (CUP 2006) 168-76; Jonathan Crowe, 'Natural Law in Jurisprudence and Politics' (2007) 27 Oxford Journal of Legal Studies 775, 791-3. 
adopts this principle. It is common for parties on both sides of a conflict to depict themselves as fighting for justice and to accuse their opponents of being at fault. If international humanitarian law imposed different rules on unjust aggressors and innocent parties, both sides of a conflict would try to exploit this for their own advantage. This would undermine the underlying goal of establishing dependable limits on warfare. The principle of neutrality therefore plays an important role in promoting universal respect for humanitarian principles.

It is worth noting, however, that the ethical underpinnings of the rules governing armed conflict are more complicated than the principle of neutrality makes it seem. International humanitarian law takes the view that it does not matter how a conflict started. The same rules apply to everyone. However, imagine that Kate is asleep in her bed when she hears a noise downstairs. She comes down to find that Andrew has broken into her house and is brandishing a gun. Kate also happens to have a gun nearby, which she keeps for self-defence. The two confront each other in Kate's living room.

Let us suppose that Kate and Andrew both see that the other is armed. They are in genuine fear for their lives. Most people would agree that Kate is entitled to defend herself from Andrew. She should probably disarm him or flee if she can, but she may use force to defend herself if necessary. Andrew, however, seems to be in a different position. He is the one who caused the altercation by wrongfully breaking into Kate's house. If Kate defends herself against Andrew and injures him, she is not culpable. However, if Andrew ends up injuring Kate, he is to blame, even if he feared for his life.

This example shows that it does make a difference who started a conflict. An innocent victim who acts in self-defence is in a different ethical position to an unjust aggressor. ${ }^{12}$ Nonetheless, international humanitarian law sets this aside and aims at the universal acceptance of a common set of rules. ${ }^{13}$ If the parties to a war were treated differently depending on their

12 For further discussion, see Michael Walzer, Just and Unjust Wars (Basic Books 1977) ch 3; Jeff McMahan, 'Innocence, Self-Defence and Killing in War' (1994) 2 Journal of Political Philosophy 193; Jeff McMahan, 'The Ethics of Killing in War' (2004) 114 Ethics 693; Gerhard Øverland, 'Killing Civilians' (2005) 13 European Journal of Philosophy 345; Gerhard Øverland, 'Killing Soldiers' (2006) 20 Ethics and International Affairs 455.

13 Compare Jeff McMahan, 'The Ethics of Killing in War' (2004) 114 Ethics 693, 730-33; David Luban, 'War Crimes: The Law of Hell' in Larry May (ed), War: Essays in Political Philosophy (CUP 2008) 270-73; Patrick Emerton and Toby Handfield, 'Order and Affray: Defensive Privileges in Warfare' (2009) 37 Philosophy and Public Affairs 382. 
ethical status, everyone would claim to be in the right. One party might claim to be above the rules and the other would retaliate. The situation would escalate. We would be on the slippery slope to absolute warfare.

\section{COHERENCE AND ACCEPTANCE}

It is instructive in this context to distinguish two aspirations that often guide the development of legal principles. The first aspiration is to create a body of norms that exhibits coherence with underlying ethical principles. The second aspiration is to achieve general acceptance of the norms that comprise the legal system; in other words, to ensure the norms are followed. Frequently, these two objectives go hand in hand. A legal system is often more likely to be respected if it contains a coherent body of rules. ${ }^{14}$

Legal systems may differ, however, in the relative levels of emphasis they place on these two aspirations. A case can be made that international humanitarian law places greater emphasis on acceptance and less on consistency with underlying ethical norms than many other fields of law. Humanitarian norms often prioritise simplicity and clarity over coherence with underlying ethical principles, since the primary aim of this body of law is to secure recognition and respect from all participants in armed conflict. The principle of neutrality, as discussed in the previous section, provides an example.

We saw above that the ethical principles governing self-defence seem to suggest that different standards apply to aggressors and innocent parties. This is what Jeff McMahan calls the 'deep morality' of warfare. ${ }^{15}$ However, as McMahan points out, the deep morality of warfare differs significantly from the law of war. ${ }^{16}$ The international law of armed conflict, then, does not derive its legitimacy from its strict coherence with the deep morality of warfare, but rather from the need for clear and generally accepted conventions to 'mitigate the savagery of war'. ${ }^{17}$ These conventions are typically founded in broad underlying values, but their most important feature may be that they are generally respected. It is only by maintaining clear, stable and predictable conventions concerning acceptable conduct on the battlefield that the international community can place reliable limits on warfare.

14 For further discussion of the value of coherence in law, see Jonathan Crowe, 'Dworkin on the Value of Integrity' (2007) 12 Deakin Law Review 167.

15 Jeff McMahan, 'The Ethics of Killing in War' (2004) 114 Ethics 693, 730.

16 Ibid 730-33.

17 Ibid 730. 


\section{DEFINING ARMED CONFLICT}

We have seen that international humanitarian law only operates during an armed conflict. The legal definition of armed conflict therefore plays a critical role in this body of law. A number of important questions arise here. How do we distinguish an armed conflict from a mere civil disturbance, such as a riot? How do we determine exactly when an armed conflict commences and when it ends? These lines may often be difficult to draw, but international courts and tribunals have offered some guidance.

Common Article 2 of the Geneva Conventions of 1949 states that the Conventions will apply to 'all cases of declared war or of any other armed conflict which may arise between two or more of the High Contracting Parties, even if the state of war is not recognised by one of them'. A declaration of war is therefore not necessary for the existence of an armed conflict. International humanitarian law comes into play whenever hostilities reach a certain threshold. The concept of armed conflict is also relevant to international criminal law, as violations of the laws and customs of war can only be prosecuted when they occur in the context of a conflict. We will return to that issue below.

Common Article 2 goes on to clarify that the provisions of the Geneva Conventions also apply in cases of total or partial occupation of a state party's territory, even when the occupation is met with no resistance. This extends the reach of the Conventions to situations where an occupation occurs without a declaration of war or armed hostilities. People who are affected by such an occupation will therefore still potentially receive the guarantees afforded to protected persons under Geneva Convention IV. The obligations of occupying powers will be discussed in greater detail in Chapter 4.

An important definition of an armed conflict comes from the International Criminal Tribunal for the Former Yugoslavia (ICTY) judgment in Prosecutor $v$ Tadic, the first case to be heard before that body. ${ }^{18}$ The Appeals Chamber in Tadić confirmed that 'for there to be a violation of [international humanitarian law], there must be an armed conflict' ${ }^{19}$ The Appeals Chamber then went on to say that 'an armed conflict exists whenever there is a resort to armed force between States or protracted armed violence between governmental authorities and organised armed

18 Prosecutor $v$ Tadić, International Criminal Tribunal for the Former Yugoslavia (ICTY) Appeals Chamber Decision on Jurisdiction, 2 October 1995.

19 Ibid [67]. 
groups or between such groups within a State'. ${ }^{20}$ This was reaffirmed in the later case of Prosecutor $v$ Kunarac. ${ }^{21}$

The definition proposed by the Appeals Chamber in Tadić recognises two distinct tests for the existence of an armed conflict. The first test refers to 'a resort to armed force between States'. This is the classic definition of an international armed conflict. It traditionally involves a formal declaration of warfare by one or both states, although this is not strictly necessary. The second test refers to 'protracted armed violence between governmental authorities and organised armed groups or between such groups within a State'. This formulation recognises that international humanitarian law may also apply to conflicts involving non-state groups. The test covers both conflicts involving a combination of states and nonstate groups and conflicts in which no states are directly involved.

Historically, the application of international humanitarian law to insurgent groups depended on the members of the group being recognised as belligerents by either the state they were opposing or a third state. If the state to which the insurgents were opposed recognised them as belligerents, the laws of war would apply in their entirety. However, this was rare and usually occurred only when it suited the recognising state. ${ }^{22}$ The applicability of the rules of international humanitarian law to a nonstate group no longer depends upon recognition of the group by a state. Rather, it depends primarily on whether or not an armed conflict exists under international law. We will examine the extent to which international humanitarian law binds non-state groups in more detail in Chapter 7.

\section{Protracted Armed Violence}

According to the ICTY Appeals Chamber in Tadic, an armed conflict involving non-state groups arises only if the violence is protracted and the non-state groups are organised. What amounts to 'protracted armed violence' within the meaning of the Tadic definition? The ICTY Trial Chamber has clarified that 'protracted armed violence' contrasts with 'banditry, unorganised and short-lived insurrections'. ${ }^{23}$ Rioting, for example, is not normally treated as an armed conflict, but merely a civil disturbance. This was reiterated by the Inter-American Commission on

\footnotetext{
20 Ibid [70].

21 Prosecutor v Kunarac, ICTY Appeals Chamber Judgment, 12 June 2002 [55]-[56].

22 Lindsay Moir, The Law of Internal Armed Conflict (CUP 2002) 4-18.

23 Prosecutor v Tadić, ICTY Trial Chamber Judgment, 7 May 1997 [562].
} 
Human Rights (IACHR) in the case of Juan Carlos Abella v Argentina. ${ }^{24}$ The IACHR stated that an armed conflict must be contrasted with 'disturbances with no concerted intent' and 'isolated and sporadic acts of violence'. 25

Among the examples given by the IACHR in Abella of situations falling short of armed conflict were violent civilian demonstrations, students throwing stones at police, bandits holding hostages for ransom and political assassinations. ${ }^{26}$ It may be difficult to draw the line in particular cases. However, the IACHR observed in Abella that 'in making such a determination, what is required in the final analysis is a good faith and objective analysis of the facts in each particular case' ${ }^{27}$ A legalistic adherence to any particular definition is inappropriate. Rather, a holistic assessment of the facts is required.

The Abella case concerned a skirmish at a military base during a time of political unrest in Argentina. The IACHR concluded that an armed conflict had occurred, even though the skirmish only lasted for 30 hours in total. Its reasoning emphasised 'the concerted nature of the hostile acts undertaken by the attackers, the direct involvement of governmental armed forces and the nature and level of the violence'. ${ }^{28}$ The IACHR noted that the case involved a 'carefully planned, coordinated and executed' armed attack against 'a quintessential military objective - a military base'. It also cited the International Committee of the Red Cross (ICRC) recommendation that the rules of international humanitarian law 'should be applied as widely as possible'. ${ }^{29}$ This reasoning suggests that, in borderline cases, there may be a presumption in favour of the existence of an armed conflict.

\section{Organised Armed Groups}

According to the ICTY Appeals Chamber in Tadić, an armed conflict involving non-state forces must involve 'organised armed groups'. Again, this standard is intended to distinguish armed conflicts from sporadic outbreaks of violence, such as riots and demonstrations. Typically, an organised armed group will have a clear chain of command. However, it is not necessary that each group involved in an armed conflict be clearly

24 Juan Carlos Abella v Argentina, Inter-American Commission on Human Rights Case No 11.137, Report No 55/97, 18 November 1997.

25 Ibid [149].

26 Ibid [154].

27 Ibid [153].

28 Ibid [155].

29 Ibid [152]. 
differentiated and defined. There may be a number of loosely related armed groups involved, as in the conflict in the former Yugoslavia. ${ }^{30}$ The ICTY Trial Chamber in the case of Prosecutor $v$ Haradinaj viewed the following factors as indicative of organisation: the existence of command structure and disciplinary rules; control of a determinate territory; access to weapons, equipment and military training; and the ability to define military strategy and use military tactics. ${ }^{31}$

No one factor can be considered determinative and whether hostilities involve organised armed groups must accordingly be considered on a caseby-case basis. The ICTY Appeals Chamber noted in the Tadić case, for example, that the main parties to the conflict in Bosnia and Herzegovina were the government of the Republic of Bosnia and Herzegovina, on the one hand, and the Bosnian Serb forces, on the other. In recognising the situation as an armed conflict under international law, the Tribunal observed that the Bosnian Serb forces exhibited various indicia of organisation, including operating under the command of the Bosnian Serb administration and occupying a determinate region. The United Nations Security Council had also taken steps to maintain peace and security in the region, including imposing an arms embargo. ${ }^{32}$ This showed that the Bosnian Serb forces had a significant military presence and were in effective control of disputed territory.

The requirement of a certain level of organisation of a group as a prerequisite for the applicability of international humanitarian law is also significant in the context of modern terrorism. Common rhetoric in relation to the 'war on terror' might give rise to a perception that armed resistance to terrorists automatically constitutes an armed conflict. However, there is a real question as to whether the kinds of loosely organised groups that often carry out terrorist activity have the requisite internal structure, based on the characteristics outlined above, to bring international humanitarian law into play. ${ }^{33}$

There is precedent in both international tribunals and the decisions of state courts to recognise terrorist groups as organised armed groups for the purpose of establishing the existence of an armed conflict. ${ }^{34}$ For example,

30 Prosecutor v Tadić, ICTY Appeals Chamber Decision on Jurisdiction, 2 October 1995 [70].

31 Prosecutor v Haradinaj, ICTY Trial Chamber Judgment, 3 April 2008 [60].

32 Prosecutor $v$ Tadić, ICTY Trial Chamber Judgment, 7 May 1997 [564], [567].

33 International Committee of the Red Cross, International Humanitarian Law and the Challenges of Contemporary Armed Conflicts (ICRC 2007) 7-8.

34 Prosecutor v Boskoski, ICTY Trial Chamber Judgment, 10 July 2008 [173][190]. 
the United States Supreme Court considered in Hamdan v Rumsfeld that the conflict that existed in Afghanistan between the United States and the terrorist group Al Qaeda in 2001 constituted a non-international armed conflict under international law, bringing it within the scope of Common Article 3 of the Geneva Conventions. ${ }^{35}$ Although sporadic and isolated acts of terrorism will be unlikely to meet the threshold, protracted terrorist violence may well do so.

Issues also arise increasingly in contemporary conflicts involving hostilities between organised crime groups within the territory of a state or between an organised crime group and government forces. Is an organised crime group capable of satisfying the criteria for an organised armed group within the meaning of the ICTY Appeals Chamber in Tadic? Although this falls to be determined on a case-by-case basis, there seems no principled reason for excluding such disputes from the definition of armed conflict as long as they meet the overarching requirements mentioned above. ${ }^{36}$

\section{SCOPE OF ARMED CONFLICT}

The existence of an armed conflict brings international humanitarian law into operation. However, an issue may arise as to whether particular acts fall within the conflict's geographical and temporal scope. In its jurisdictional decision in the Tadic case, the ICTY Appeals Chamber observed that 'the temporal and geographical scope [of the conflict] extends beyond the exact time and place of hostilities'. At least some aspects of international humanitarian law apply within the 'entire territory' of the parties for the duration of the conflict. ${ }^{37}$ It follows that 'a violation of the laws or customs of war may [. . .] occur at a time when and in a place where no fighting is actually taking place'. ${ }^{38}$ In the case of non-international conflicts, international humanitarian law applies in so much of the territory as is under the control of one or more of the parties to the conflict. ${ }^{39}$

The temporal reach of international humanitarian law, on the other

\footnotetext{
35 Hamdan v Rumsfeld 548 US 557, 629-31 (2006).

36 International Committee of the Red Cross, International Humanitarian Law and the Challenge of Contemporary Armed Conflicts (ICRC 2011) 9-12.

37 Prosecutor v Tadić, ICTY Appeals Chamber Decision on Jurisdiction, 2 October 1995 [67]-[68].

38 Prosecutor v Kunarac, ICTY Appeals Chamber Judgment, 12 June 2002 [64].

39 Prosecutor v Tadić, ICTY Appeals Chamber Decision on Jurisdiction, 2 October 1995 [64], [70].
} 
hand, extends from the initiation of hostilities until 'a general conclusion of peace is reached' ${ }^{40}$ Declaration of an armistice or ceasefire does not have the effect of terminating an armed conflict unless it constitutes a peace agreement and is followed by a general cessation of hostilities. A temporary cessation of hostilities does not mean international humanitarian law ceases to apply. The Geneva Conventions specifically provide for the temporal application of international humanitarian law in respect of particular groups. Prisoners of war, for example, gain the protection of Geneva Convention III from the time they fall into the power of the enemy until their final release and repatriation. ${ }^{41}$

The provisions of Geneva Convention IV apply from the outset of the conflict until the general close of military operations. Those aspects of Geneva Convention IV governing occupied territories are further stipulated to apply for one year after the general close of military operations, with the exception of some articles that apply until the occupying power ceases to exercise the functions of government. ${ }^{42}$ The position has now been clarified by Additional Protocol I of 1977, which states that all provisions applicable to occupation continue to operate until the occupation terminates.

\section{Connection to the Conflict}

A further issue arises in the context of international criminal law. The ICTY has held that a charge of violating the laws and customs of war can only be established if the acts have an appropriate connection to the armed conflict. It is not enough that the acts occur at the same time and place as the conflict. Rather, they must take place in the context of the conflict. ${ }^{43} \mathrm{In}$ the words of the ICTY Appeals Chamber: 'The existence of an armed conflict must, at a minimum, have played a substantial part in the perpetrator's ability to commit [the crime, the] decision to commit it, the manner in which it was committed or the purpose for which it was committed. ${ }^{44}$

This requirement is necessary to distinguish acts committed during an armed conflict that properly fall within international humanitarian law from those that properly fall under domestic law. For example, an ordinary theft or assault during wartime would not fall within international

\footnotetext{
40 Ibid [70].

41 Geneva Convention III, art 5.

42 Geneva Convention IV, art 6.

43 Prosecutor $v$ Tadić, ICTY Appeals Chamber Decision on Jurisdiction, 2 October 1995 [69].

44 Prosecutor v Kunarac, ICTY Appeals Chamber Judgment, 12 June 2002 [58].
} 
humanitarian law, but would be dealt with under domestic law, as it would be in peacetime. On the other hand, ethnically motivated assaults during the Yugoslavian and Rwandan conflicts have been treated as violations of international humanitarian law, since the motivation was related to the conflict. 45

The ICTY Appeals Chamber has made it clear that an act may be sufficiently related to the conflict to enliven international humanitarian law, even though it does not occur 'in the midst of battle'. ${ }^{46}$ The Appeals Chamber judgment in Kunarac sets out a list of factors that may be considered in assessing whether an act is related to the conflict. These include: the fact that the perpetrator is a combatant; the fact that the victim is a non-combatant; the fact that the victim is from a group associated with the enemy; the fact that the act may be said to serve the ultimate goal of a military campaign; and the fact that the crime is committed as part of or in the context of the perpetrator's official duties. ${ }^{47}$

The Kunarac case concerned a systematic campaign of rape and other forms of abuse perpetrated by Bosnian Serb military personnel against Bosnian Muslim women during the armed conflict in the former Yugoslavia. The ICTY Trial Chamber had no difficulty in establishing a connection between the assaults and the conflict. The crimes were both facilitated and motivated by the conflict; as the Trial Chamber observed, 'Muslim civilians were killed, raped or otherwise abused as a direct result of the armed conflict and because the armed conflict apparently offered blanket impunity to the perpetrators' ${ }^{48}$ This finding was later endorsed by the ICTY Appeals Chamber. ${ }^{49}$

\section{TYPES OF ARMED CONFLICTS}

International humanitarian law has traditionally distinguished between international and non-international armed conflicts. Prior to the Geneva

45 See, for example, Prosecutor v Delalic, ICTY Trial Chamber Judgment, 16 November 1998; Prosecutor v Kvocka, ICTY Trial Chamber Judgment, 2 November 2001; Prosecutor v Jean Paul Akayesu, International Criminal Tribunal for Rwanda Trial Chamber Judgment, 2 September 1998.

46 Prosecutor $v$ Tadić, ICTY Appeals Chamber Decision on Jurisdiction, 2 October 1995 [69]; Prosecutor v Kunarac, ICTY Appeals Chamber Judgment, 12 June 2002 [60].

47 Prosecutor v Kunarac, ICTY Appeals Chamber Judgment, 12 June 2002 [59].

48 Prosecutor v Kunarac, ICTY Trial Chamber Judgment, 22 February 2001 [568].

49 Prosecutor v Kunarac, ICTY Appeals Chamber Judgment, 12 June 2002 [64]. 
Conventions of 1949, it was generally thought that civil conflicts were outside the scope of international law. They were a matter for states to deal with internally. However, there was growing international awareness of the need for regulation in this area, fuelled by the bloody and protracted nature of conflicts such as the Spanish Civil War (1936-1939). The importance of placing limits on internal armed conflicts has only increased since then. Since the Second World War, the vast majority of armed conflicts have been non-international in character. ${ }^{50}$

The requirements of international humanitarian law still differ between international and non-international conflicts. However, the distinction has for some time been diminishing in importance, as we will see in more depth below. It is now widely accepted that some common guarantees apply in conflicts of both types. ${ }^{51}$ Common Article 3 of the Geneva Conventions was the first, and for some time the only, provision to bring non-international conflicts within the reach of international humanitarian law. It was supplemented by the adoption of Additional Protocol II to the Geneva Conventions in 1977.

The rationale behind the protections contained in Common Article 3 is that there are certain principles of humanity so fundamental that they apply to combatants and civilians in all kinds of conflict. Prior to 1949, the Geneva Conventions assisted only persons caught up in international conflicts. Belligerent groups in civil conflicts were widely perceived as domestic criminals and attempts by the Red Cross Movement to aid those belligerents as inadmissible aid. ${ }^{52}$ For this reason, suggestions that the Conventions in their entirety should be applied to non-international conflicts were rejected; their implementation would have greatly restricted states in their capacity to deal with insurgents, including having to treat them as prisoners of war, rather than using ordinary criminal procedures. ${ }^{53}$ Common Article 3 is accordingly limited to the most fundamental of principles underlying the Geneva Conventions; it could not be said that

50 Jean-Marie Henckaerts and Louise Doswald-Beck, Customary International Humanitarian Law (CUP 2005) xxviii; Lindsay Moir, The Law of Internal Armed Conflict (CUP 2002) 1; Dan Smith, The State of War and Peace Atlas (Penguin 1997) 90-95; International Committee of the Red Cross, International Humanitarian Law and the Challenge of Contemporary Armed Conflicts (ICRC 2011) 6.

51 Prosecutor v Tadić, ICTY Appeals Chamber Decision on Jurisdiction, 2 October 1995 [96]-[127].

52 Jean S Pictet et al (eds), Commentary on the Geneva Conventions (ICRC 1960) vol 3, 28-9.

53 Ibid 32 . 
torture or mutilation, for example, are reasonable measures for a state to suppress a rebellion against it by an insurgent group. ${ }^{54}$

A distinction needs to be drawn in this context regarding the scope of Common Article 3 and Additional Protocol II. Common Article 3 has the broader scope of the two. It applies to armed conflicts 'not of an international character' occurring in the territory of a state party. Additional Protocol II, on the other hand, applies to armed conflicts not covered by Additional Protocol I that take place in the territory of a state party between its armed forces and dissident armed forces or other armed groups. The non-state groups in question must be under responsible command, and control enough of the state's territory to carry out 'sustained and concerted military operations' and to implement the Protocol. ${ }^{55}$ The more limited scope of Additional Protocol II occurred as a result of fears by a number of states who negotiated the text of the Additional Protocols that an expansive field of application would limit their ability to deal effectively with internal disturbances.

It therefore appears that Additional Protocol II will technically only apply to armed conflicts where one of the parties is a state, whereas the principles expressed in Common Article 3 potentially apply to conflicts where no states are involved. It has been suggested that both state and non-state participants in internal armed conflicts are bound by Common Article 3 by virtue of its customary law status. ${ }^{56}$ Additional Protocol II is also expressly stated not to apply to internal disturbances and tensions, such as riots, isolated and sporadic acts of violence' and other similar incidents. ${ }^{57}$ It therefore reiterates the overarching definition of armed conflict discussed earlier in this chapter.

\section{Definitional Issues}

We have seen that the definition of armed conflict offered by the ICTY Appeals Chamber in Tadic has two limbs, corresponding to international and non-international conflicts. An international armed conflict, according to this definition, is a conflict between the armed forces of two or

54 Ibid 36-7.

55 Additional Protocol II, art 1(1).

56 For discussion, see Sandesh Sivakumaran, 'Binding Armed Opposition Groups' (2006) 55 International and Comparative Law Quarterly 369, 371-5. Compare Nicaragua v United States (Merits), International Court of Justice (ICJ) Judgment, 27 June 1986 [218]-[219]. We will return to this issue in Chapter 7.

57 Additional Protocol II, art 1(2). 
more states. ${ }^{58} \mathrm{~A}$ non-international armed conflict, on the other hand, is a conflict between a state and an organised armed group within the state's territory or between two or more non-state groups within a state's territory.

The distinction between international and non-international conflicts is not always straightforward. For example, it may depend whether a particular entity is legally recognised as a state. Would a war between China and Taiwan be international or non-international? What about border skirmishes between Somaliland and Puntland? The answer potentially depends on how one interprets the criteria for statehood under international law. We will examine that topic in more detail in Chapter 7.

The ICTY Appeals Chamber described the conflict in the former Yugoslavia as having 'both internal and international aspects'. ${ }^{59}$ This shows that the distinction may be ambiguous, even in the absence of disputes concerning statehood. The status of the Yugoslavian conflict was complicated by the multiple state and non-state parties involved. In some cases, a non-international armed conflict may become international at a certain point in its history. This is often referred to as an 'internationalised' conflict. A conflict may become internationalised because of the creation of a new state or states during the conflict. Alternatively, internationalisation may occur when a third-party state militarily intervenes in a non-international conflict or when one or more participants in a non-international conflict come to act 'on behalf of' a third-party state. ${ }^{60}$

\section{The Test of Control}

When is a party to a non-international conflict deemed to be acting 'on behalf of ' a third-party state, thereby internationalising the conflict? Two tests for resolving this question have been mooted. The first test arises from the International Court of Justice (ICJ) decision in the case of Nicaragua $v$ United States. ${ }^{61}$ In that case, the ICJ held a party is acting on behalf of a state if the state has 'effective control' over the group. ${ }^{62}$ This is a high standard, requiring the state to issue the group with instructions

\footnotetext{
58 Prosecutor v Tadić, ICTY Appeals Chamber Judgment, 15 July 1999 [84].

59 Prosecutor v Tadić, ICTY Appeals Chamber Decision on Jurisdiction, 2 October 1995 [77].

60 Ibid; Prosecutor v Tadić, ICTY Appeals Chamber Judgment, 15 July 1999 [88]-[97].

61 Nicaragua v United States (Merits), ICJ Judgment, 27 June 1986.

62 Ibid [115].
} 
to commit specific acts. It is not enough that the state provides technical support or financial assistance.

The primary issue before the ICJ in Nicaragua was not whether the conflict in question was international or non-international, but rather whether the United States could be held responsible for acts performed by a non-state guerrilla group fighting against the Nicaraguan government. However, the ICTY Appeals Chamber in Tadic treated the test as relevant to the classification of armed conflicts. The ICJ in Nicaragua presented the effective control test as generally applicable to determining state responsibility for the actions of non-state groups. The ICTY Appeals Chamber, on the other hand, ruled that the test only applies to the control of individuals and disorganised groups. ${ }^{63}$

According to the Appeals Chamber, control of organised groups is assessed using the weaker 'overall control' test. ${ }^{64}$ The overall control test asks whether the state 'wields general control over the group, not only by equipping and financing [it], but also by coordinating or helping in the general planning of its military activity'. ${ }^{65}$ It does not require that the state issues directions to perform specific acts, but merely that the state has an overall relationship of influence and control over the group. The rationale for the two different tests seems to be that the actions of organised groups are generally more predictable than those of disorganised groups or individuals. It is therefore reasonable to hold a state responsible for the actions of an organised group based on an overall relationship of control, while for disorganised groups and individuals specific directions are needed.

The Appeals Chamber further held that "where the controlling State in question is an adjacent State with territorial ambitions on the State where the conflict is taking place [...] it may be easier to establish the threshold'. ${ }^{66}$ This suggests a holistic approach to determining whether a non-state group is acting on behalf of a state. If a third-party state has an obvious interest in the success of a rebel group operating on the territory of another state, an inference may more easily be drawn based on technical and material assistance that the group is operating on the third party's behalf.

\footnotetext{
63 Prosecutor v Tadić, ICTY Appeals Chamber Judgment, 15 July 1999 [99][100].

64 Ibid [120].

65 Ibid [131].

66 Ibid [140].
} 


\section{Wars of National Liberation}

Additional Protocol I to the Geneva Conventions generally applies to the same types of armed conflicts covered by Common Article 2: namely, international conflicts between state parties. ${ }^{67}$ However, Article 1(4) of Additional Protocol I extends its scope to a type of conflict not covered by Common Article 2: 'armed conflicts in which peoples are fighting against colonial domination and alien occupation and against racist regimes in exercise of their right of self-determination'. Conflicts falling into this category are commonly called wars of national liberation. They are deemed international conflicts for the purposes of Additional Protocol I, although they would otherwise count as internal conflicts.

Article 96(2) of Additional Protocol I provides that state parties are not obliged to observe its provisions in relation to states or other parties to a conflict that do not accept it as binding. Article 96(3) then sets out a procedure whereby non-state groups engaged in wars of national liberation may formally undertake to apply the Protocol. These provisions effectively mean that the Protocol is not binding in wars of national liberation unless the non-state groups involved have recognised its application.

The definition of a war of national liberation in Article 1(4) is open to interpretation. It makes reference to the concept of self-determination, which itself is not very clearly delineated under international law. Furthermore, it is very much open to dispute whether a particular armed group is fighting against 'colonial domination', 'alien occupation' or a 'racist regime'. These kinds of terms tend to feature in political rhetoric rather than being framed for technical accuracy. They are therefore unsuited to determining legal questions such as the status of an armed conflict. Furthermore, it is unlikely that a state would be willing to voluntarily label itself as colonial, alien or racist when facing internal armed dissent. The inclusion of wars of national liberation in Additional Protocol I has therefore long been controversial. The scope of the provision remains poorly defined.

\section{The Future of the Distinction}

It has been suggested by a number of judges and commentators that the distinction between international and non-international armed conflicts is gradually diminishing in importance. ${ }^{68}$ Some, but certainly not all, rules

\footnotetext{
67 Additional Protocol I, art 1(3).

68 For a helpful overview, see Emily Crawford, 'Unequal Before the Law:
} 
governing international armed conflicts have become applicable to internal conflicts as a matter of customary international law. ${ }^{69}$ Furthermore, the nature of contemporary armed conflicts means the distinction is not always obvious, as the Yugoslavian conflict illustrates.

Non-international conflicts not infrequently possess an extraterritorial aspect - for example, incursions over state borders - and may feature the involvement of international forces either fighting alongside the parties or acting in a peacekeeping capacity. Conflicts may also arise between a state and a non-state party operating from the territory of another state but not under that state's authority or control, such as the 2006 conflict between Israel and Hezbollah forces operating from within Lebanon. ${ }^{70}$

The increasingly diverse nature of armed conflict continues to challenge the delineation of the boundaries between types of conflict. The ICTY Appeals Chamber commented in the Tadic decision on jurisdiction that since the 1930s the distinction between international and non-international conflict has become increasingly blurred. The Appeals Chamber attributed this to various factors, including the increasing frequency and protracted nature of civil conflicts, sometimes involving the whole population of the state where they occur. The increasing interdependence of states in the modern world also means that armed violence within one state will impact on the interests of other nations, making them more likely to have an interest in the resolution of such internal conflicts. ${ }^{71}$

Finally and perhaps most importantly, the Appeals Chamber pointed to the emergence of human rights doctrines and to their gradual assumption of importance relative to traditional notions of state sovereignty:

Why protect civilians from belligerent violence, or ban rape, torture or the wanton destruction of hospitals, churches, museums or private property, as well as proscribe weapons causing unnecessary suffering when two sovereign States are engaged in war, and yet refrain from enacting the same bans or providing the same protection when armed violence has erupted 'only' within the territory of a sovereign State? ${ }^{72}$

The Case for the Elimination of the Distinction Between International and NonInternational Armed Conflicts' (2007) 20 Leiden Journal of International Law 441.

69 Jean-Marie Henckaerts and Louise Doswald-Beck, Customary International Humanitarian Law (CUP 2005) xxix.

70 International Committee of the Red Cross, International Humanitarian Law and the Challenge of Contemporary Armed Conflicts (ICRC 2011) 9-11.

71 Prosecutor v Tadić, ICTY Appeals Chamber Decision on Jurisdiction, 2 October 1995 [97].

72 Ibid [97]. 
Developments in technology have contributed significantly to the expansion of international humanitarian law to cover a broader range of conflicts. Now more than ever, the suffering of people embroiled in conflicts around the world is instantly transmitted to wide international audiences through the internet and social media platforms. These new technologies have given the notion of cosmopolitanism referred to earlier in this chapter new meaning, as it allows us to witness the experiences of other global citizens in a way that could not have been imagined in Diogenes' time.

The atrocities perpetrated on a large scale during the civil conflict in Rwanda in the 1990s, and the international community's failure to act, brought home to people around the world the need for civilians to be granted protection in internal conflicts, regardless of principles of state sovereignty. More recently, media coverage of hostilities between state governments and national liberation forces has highlighted the suffering of citizens and reinforced the need for certain minimum standards of protection to apply to victims of all conflicts, regardless of their nature.

While these developments do not mean that all rules applicable to international conflicts now apply to non-international conflicts, it is certainly the case that a number of rules and principles now apply regardless of the nature of the conflict. These rules include protection of civilians from hostilities, protection of civilian objects, and the prohibition of certain means of warfare and methods of conducting hostilities. ${ }^{73}$ In 2005, a study commissioned by the ICRC found that of 161 customary principles of international humanitarian law, 148 applied in non-international as well as international armed conflicts. ${ }^{74}$ The recognition of these principles of customary international law may mean that the distinction between types of conflict is of much less significance that it has been in the past.

3 Ibid [126]-[127].

74 Jean-Marie Henckaerts and Louise Doswald-Beck, Customary International Humanitarian Law (CUP 2005). The figures are reported in International Committee of the Red Cross, International Humanitarian Law and the Challenge of Contemporary Armed Conflicts (ICRC 2011) 12. 